\title{
KONTRIBUSI KOMPONEN TEKNOLOGI INDUSTRI PENGOLAHAN COKELAT (STUDI KASUS CV. X)
}

\author{
Technology Components Contribution of Chocolate Processing Industry \\ (Case Study of CV. X)
}

\author{
Ratri Retno Utami ${ }^{1}$, Zuhrawaty ${ }^{2}$, dan Tristania Pranasari ${ }^{3}$ \\ ${ }^{1}$ Balai Besar Industri Hasil Perkebunan, \\ Jl. Prof. Abdurahman Basalamah No.28, Makassar, Sulawesi Selatan 90231 \\ ${ }^{2}$ Balai Riset dan Standardisasi Industri Pontianak, \\ JI. Budi Utomo No.41, Siantan Hilir, Pontianak Utara, Pontianak, Kalimantan Barat 78243 \\ ${ }^{3}$ Badan Pengembangan Sumber Daya Manusia Industri, \\ JI. Widya Chandra VIII, Senayan, Kebayoran Baru, Jakarta Selatan, DKI Jakarta 12950 \\ e-mail: ratri.retno.u@gmail.com
}

\begin{abstract}
Technology is determining factor in the formation of industrial competitiveness. The technological components include technoware, humanware, infoware, and orgaware. The purpose of this study is to calculate the value of the contribution of technology component (TCC) and determine the recommendations for developing technology components in the CV. $X$. The technology component measured using technometric and Analytical Hierarchy Process method to determine CV. X position between its competitors. Based on result, obtained TCC values of 0.3966 (bad to moderate), so that the CV. X needs to make improvements in technology components that have the lowest contribution value. The technology component with the highest contribution value of the technology component is infoware (0.488) so that it becomes a improvement priority at CV. X. Gap analysis, showing that CV. X has a lower TCC value than its competitors, with components that are still lagging behind are technoware and software. The recommendation for improving technology components is to improve all technology components accordance with development priorities.
\end{abstract}

Keywords: technometric, Analytical Hierarchy Process, cocoa processing industry, gap analysis

\begin{abstract}
Abstrak: Teknologi merupakan faktor penentu terbentuknya daya saing industri. Komponen teknologi antara lain technoware, humanware, infoware, dan orgaware. Tujuan penelitian adalah menghitung nilai koefisien kontribusi komponen teknologi (TCC) dan menentukan rekomendasi strategi pengembangan komponen teknologi di CV. X. Komponen teknologi ini diukur menggunakan metode teknometrik dan Analytical Hierarchy Process untuk menentukan posisi suatu industri dibandingkan dengan pesaingnya. Hasil perhitungan TCC diperoleh nilai 0,3966 (buruk hingga sedang), sehingga CV. X perlu melakukan perbaikan pada komponen teknologi yang memiliki nilai kontribusi paling rendah. Komponen teknologi dengan nilai intensitas kontribusi komponen teknologi paling tinggi adalah infoware $(0,488)$ sehingga menjadi prioitas pengembangan di CV. X. Analisis gap, menunjukkan bahwa CV. X mempunyai nilai TCC yang lebih rendah dari kompetitornya, dengan komponen yang masih tertinggal adalah technoware dan orgaware. Rekomendasi strategi perbaikan komponen teknologi adalah memperbaiki semua komponen teknologi sesuai dengan prioritas pengembangan.
\end{abstract}

Kata kunci: teknometrik, Analytical Hierarchy Process, industri pengolahan cokelat, analisis gap

\section{PENDAHULUAN}

Tingkat kesiapan teknologi mempunyai dua lingkup, yang pertama adalah sebagai ukuran/indikator seberapa siap teknologi dapat diterapkan oleh pengguna yang dinilai dengan metode teknometer TRL
(Technology Readiness Level) skala 19. Badan Pengkajian dan Penerapan Teknologi mengembangkan TRL untuk mendukung kolaborasi bagi inovasi, meningkatkan difusi inovasi hasil litbangyasa (BPPT, 2012). Lingkup kedua adalah tingkat kecanggihan 
teknologi lembaga/perusahaan dalam melakukan proses produksi, yang dinilai dengan menggunakan metode teknometrik dengan hasil pengukuran berupa nilai TCC (Technology Contribution Coefficient) skala 0-1 (Virliantarto, 2017).

Era globalisasi ditandai dengan berkembangnya teknologi dan persaingan yang semakin ketat. Persaingan global timbul pada saat suatu wilayah yang bersaing untuk mendapatkan pangsa pasar dan kesempatan. Agar mampu menghadapi persaingan global, maka perusahaan harus menyusun strategi bersaing yang berbasis pada kompetensi inti yang meliputi teknologi, harga, kualitas, dan fleksibilitas biaya produksi. Teknologi merupakan faktor yang sangat menentukan dalam menciptakan keunggulan daya saing dari suatu perusahaan. Teknologi dalam perubahannya berperan penting dalam perubahan struktur industri serta terciptanya industri baru. UNESCAP mengembangkan model penilaian teknologi berdasarkan empat komponen pembentuk teknologi yang berkontribusi dalam transformasi input menjadi output (Nazaruddin, 2008). Komponen pembentuk teknologi tersebut, yaitu technoware, humanware, infoware dan orgaware (UNESCAP, 1988). Technoware merupakan object embodied technology yang meliputi fasilitas fisik seperti instrumen, peralatan permesinan, alat pengangkutan dan infrastruktur fisik. Humanware merupakan teknologi yang melekat pada manusia (person embodied technology) yang meliputi kemampuan yang dimiliki seperti pengetahuan (knowledge), keterampilan (skill), kebijakan (wisdom), kreativitas (creativity) dan pengalaman (experience). Infoware merupakan document embodied technology yang meliputi seluruh fakta dan gambar yang diperlukan dalam operasi transformasi seperti informasi tentang proses (process), prosedur, teknik, metoda, teori, spesifikasi, pengamatan (observation) dan keterkaitan (relation). Orgaware merupakan teknologi yang melekat pada kelembagaan (institution embodied technology) yang mencakup kerangka kerja yang diperlukan pada operasi transformasi setiap praktek manajemen (management practice), linkage dan pengaturan organisasi (organizational arrangement) (Wiratmadja, 2011; UNESCAP, 1989 dalam Budikania, 2008). Komponen teknologi diukur dengan menggunakan Metode Teknometrik (Anshori, 2005).

Industri Kecil dan Menengah (IKM) di Indonesia memegang peranan sentral dan strategis dalam pembangunan ekonomi kerakyatan dan penyerapan tenaga kerja. Pola pengembangan dan kebijakan IKM yang terarah akan menciptakan IKM yang menjadi tulang punggung (backbone) bangkitnya sektor riil di daerah (Mubin, 2007). Tetapi permasalahanpermasalahan yang membelit IKM masih sangat kompleks, seperti permasalahan teknologi, permodalan, manajemen, pemasaran, dan masalah lingkungan. Permasalahan ini yang menyebabkan kinerja IKM yang lebih rendah dibandingkan dengan kinerja Industri Menengah dan Besar (Anshori, 2005).

Indonesia merupakan produsen biji kakao tetapi hilirisasi industri pengolahan cokelat skala IKM di Indonesia masih tertinggal dibandingkan negara-negara pengimpor biji kakao seperti Belgia dan Swiss. Pengembangan industri hilir kakao berskala IKM terkendala oleh tiga hal pokok, yaitu formulasi produk, perekayasaan proses dan ketersediaan alat dan mesin yang terjangkau, baik dari segi harga maupun operasionalisasinya. Sistem produksi hilir kakao secara umum masih dikuasai oleh industri besar karena teknologi pengolahan kakao secara teknis dan ekonomis tidak aplikatif untuk IKM. Hasil rancang bangun dan perekayasaan industri dari bengkel-bengkel kecil juga belum sepenuhnya memenuhi syarat pengolahan cokelat skala IKM baik dari aspek efisiensi pengolahan dan kualitas untuk dapat menghasilkan produk berdaya saing (Edy dan Mulato, 2010). 
CV. X merupakan salah satu industri kecil menengah yang mengolah kakao menjadi produk cokelat juga menghadapi permasalahan terkait pemilihan teknologi dalam mengembangkan perusahaan. CV. X berdiri pada tahun 2005 dengan daerah pemasaran dimulai dari Jawa dan Bali. CV. X saat ini telah melakukan ekspansi pemasaran ke seluruh Indonesia dan beberapa negara seperti Malaysia serta Singapura. Omzet awal berdirinya CV. X sekitar 70 juta rupiah per tahun dan saat ini mencapai miliaran rupiah per tahun. Penelitian ini dilakukan untuk mengetahui posisi atau kondisi komponen teknologi CV. $\mathrm{X}$ dibandingkan kompetitor sehingga dapat digunakan sebagai dasar pengembangan komponen teknologi. Sebagai kompetitor maka dipilih PT. Y dengan pertimbangan bahwa selama ini PT. Y menguasai sebagian besar pasar cokelat bar (cokelat batang) yang merupakan produk utama CV. X dan kedepannya CV. X akan dikembangkan menjadi PT. Untuk itulah diperlukan kajian tentang strategi teknologi yang tepat untuk diterapkan di CV. X. Tujuan penelitian ini adalah untuk menentukan nilai koefisien kontribusi komponen teknologi (TCC) dan rekomendasi strategi pengembangan komponen teknologi di CV. X.

\section{METODOLOGI}

Objek penelitian adalah CV. X dan penilaian intensitas kontribusi komponen teknologi $(\beta)$ dilakukan oleh manajer CV. X. Kompetitor adalah PT. Y yang merupakan industri pengolahan cokelat skala besar. Peralatan penelitian antara lain kuesioner. Asumsi penelitian ini bahwa manajer CV. X mengetahui derajat kepentingan dari masing-masing komponen teknologi (Technoware, Humanware, Infoware dan Orgaware) pada perusahaannya dengan intensitas kontribusi komponen $\beta_{T}+\beta_{H}+\beta_{I}+$ $\beta_{O}=1$.

Penilaian teknologi dilakukan
sebagai dasar perumusan strategi
teknologi pada CV. X menggunakan
model teknometrik (UNESCAP, 1988),
seperti terdapat pada Gambar 1.

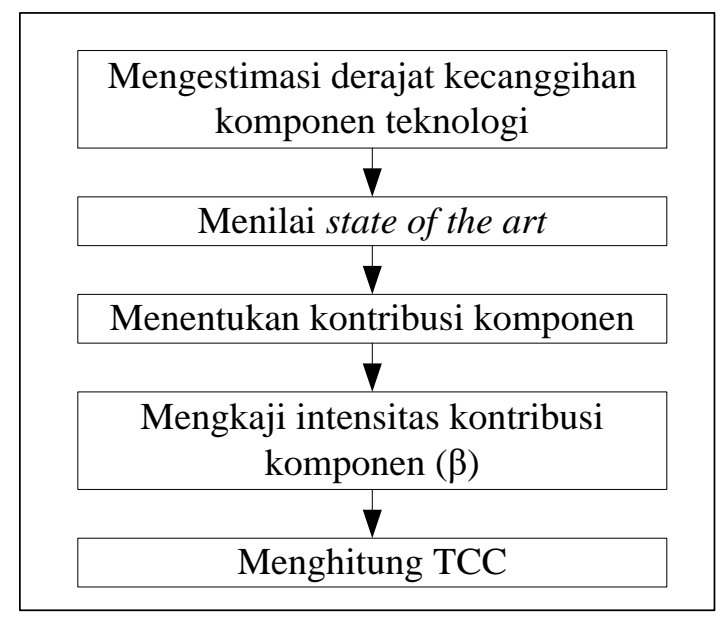

Gambar 1. Tahapan penilaian teknologi dengan model teknometrik

Estimasi derajat kecanggihan komponen teknologi

Estimasi derajat kecanggihan komponen teknologi mengacu pada Tabel 1 dan dilakukan melalui langkahlangkah sebagai berikut:
- Mengumpulkan data derajat kecanggihan komponen teknologi

- Pengamatan kualitatif terhadap THIO tingkat perusahaan

- Evaluasi THIO dan pemberian skor untuk menentukan derajat kecanggihan 
Tabel 1. Pemberian Skor Derajat Kecanggihan Teknologi (Indrawati, 2003)

\begin{tabular}{|c|c|c|c|c|}
\hline \multicolumn{4}{|c|}{ Derajat Kecanggihan Komponen Teknologi } & \multirow[t]{2}{*}{ Skor } \\
\hline Technoware & Humanware & Infoware & Orgaware & \\
\hline Mesin manual & $\begin{array}{l}\text { Kemampuan } \\
\text { mengoperasikan }\end{array}$ & Mengenal fakta & Mencari bentuk pola kerja & 123 \\
\hline Mesin bermotor & Kemempuan menge-set & Menerangkan fakta & Menetapkan pola kerja & 234 \\
\hline Mesin serbaguna & Kemampuan mereparasi & Menspesifikasikan fakta & Menciptakan pola kerja baru & 345 \\
\hline Mesin khusus & $\begin{array}{l}\text { Kemampuan } \\
\text { mereproduksi }\end{array}$ & Menggunakan fakta & Melindungi pola kerja & 456 \\
\hline Mesin otomatis & $\begin{array}{l}\text { Kemampuan } \\
\text { mengadaptasi }\end{array}$ & Menghayati fakta & Menstabilkan pola kerja & 567 \\
\hline Mesin berkomputer & $\begin{array}{l}\text { Kemampuan } \\
\text { menyempurnakan }\end{array}$ & $\begin{array}{l}\text { Menggeneralisasikan } \\
\text { fakta }\end{array}$ & Memapankan pola kerja & 678 \\
\hline Mesin terpadu & Kemampuan inovasi & Mengkaji fakta & $\begin{array}{l}\text { Menguasai } \\
\text { unggulan }\end{array}$ & 789 \\
\hline
\end{tabular}

\section{Menilai state of the art (SOTA)}

SOTA merupakan tingkat kompleksitas setiap komponen teknologi. Penentuan SOTA memerlukan pengetahuan teknis yang dalam (Hany, 2000). Rating SOTA untuk setiap komponen teknologi (Wiratmaja \& Ma'ruf, 2004):

\section{a. Technoware}

$$
S T=\frac{1}{10}\left[\frac{\sum_{k} t_{k}}{k_{t}}\right] k(\text { kriteria } k e . . .)=
$$

$1,2,3, \ldots, k_{t} \quad(1)$

$t_{k}$ adalah skor kriteria technoware ke$\mathrm{k}$

b. Humanware

$$
S H=\frac{1}{10}\left[\frac{\sum_{k} h_{k}}{k_{t}}\right] k(\text { kriteria } k e . . .)=
$$

$1,2,3, \ldots, k_{t} \quad(2)$

$h_{k}$ adalah skor kriteria humanware ke-k

c. Infoware

$$
\begin{aligned}
& S I=\frac{1}{10}\left[\frac{\sum_{k} i_{k}}{k_{t}}\right] k(\text { kriteria } k e . . .)= \\
& 1,2,3, \ldots, k_{t}(3) \\
& \mathrm{i}_{\mathrm{k}} \text { adalah skor kriteria infoware ke-k }
\end{aligned}
$$

d. Orgaware

$$
\begin{aligned}
& S O=\frac{1}{10}\left[\frac{\sum_{k} o_{k}}{k_{t}}\right] k(\text { kriteria } k e . . .)= \\
& 1,2,3, \ldots, k_{t}(4) \\
& \mathrm{O}_{\mathrm{k}} \text { adalah skor kriteria orgaware ke-k }
\end{aligned}
$$

Menentukan kontribusi komponen

$$
\text { Menentukan }
$$

kontribusi

komponen dengan menggunakan nilainilai dari batasan derajat kecanggihan dan SOTA.

$$
\begin{aligned}
& T=\frac{1}{9}[L T+S T(U T-L T)] \\
& H=\frac{1}{9}[L H+S H(U H-L H)] \\
& I=\frac{1}{9}[L I+S I(U I-L I)] \\
& O=\frac{1}{9}[L O+S O(U O-L O)]
\end{aligned}
$$

Mengkaji intensitas kontribusi komponen ( $\beta)$

Intensitas kontribusi komponen dapat dilakukan dengan bantuan matrik perbandingan berpasangan dan Analytical Hierarchy Process. Prosedur estimasinya yaitu:

a. Keempat komponen teknologi diatur secara hirarki dengan urutan kepentingan meningkat. Nilai $\beta$ yang berkaitan dengan komponenkomponen ini diatur dalam urutan kepentingan yang sama

b. Nilai-nilai tersebut ditransformasikan ke dalam prosedur perbandingan berpasangan

c. Perbandingan berpasangan harus memenuhi syarat konsistensi, artinya memenuhi syarat ordinal. Secara umum dapat dikatakan bahwa bila suatu komponen memiliki urutan tingkat kepentingan lebih besar dari komponen lainnya, maka nilai $\beta$ komponen tersebut akan lebih besar dari yang lainnya

Rata-rata Geometrik (Geometric Mean) 
Nilai $\beta$ yang didapatkan dari kuesioner perbandingan berpasangan dirata-rata terlebih dahulu dengan menggunakan rata-rata geometrik. Rata-rata geometrik $a_{i j}$ dari $k$ nilai perbandingan antara kriteria ke i dengan kriteria ke j mengikuti formula berikut: $a_{i j}$ : nilai rata-rata perbandingan antara kriteria ke i dengan kriteria ke j $b_{i}$ : nilai perbandingan antara kriteria ke i dengan kriteria ke j untuk responden ke $\mathrm{i}, \mathrm{i}=1,2, \ldots, \mathrm{k}$ $k$ : banyaknya responden yang terlibat sebagai responden $a_{i j}=\left(b_{1} x b_{2} x \ldots x b_{k}\right)^{1 / k}$

\section{Dimana:}

Tabel 2. Skala Tingkat Kepentingan Relatif untuk Menghitung Intensitas Kontribusi Komponen

Intensitas Definisi Keterangan

\begin{tabular}{|c|c|c|}
\hline & & \\
\hline 1 & Sama pentingnya & $\begin{array}{l}\text { Dua aktivitas memberikan kontribusi yang } \\
\text { sama terhadap sebuah tujuan }\end{array}$ \\
\hline 3 & Agak lebih penting daripada & $\begin{array}{l}\text { Suatu aktivitas terbukti lebih penting } \\
\text { dibandingkan aktivitas lainnya, tetapi kelebihan } \\
\text { tersebut kurang meyakinkan atau tidak } \\
\text { sianifikan }\end{array}$ \\
\hline 5 & Lebih penting daripada & $\begin{array}{l}\text { Terdapat bukti yang bagus dan kriteria yang } \\
\text { logis yang menyatakan bahwa salah satu } \\
\text { aktivitas memang lebih penting daripada } \\
\text { aktivitas lainnya }\end{array}$ \\
\hline 7 & Jauh lebih penting daripada & $\begin{array}{l}\text { Salah satu aktivitas lebih penting dibandingkan } \\
\text { aktivitas lainnya dapat dibuktikan secara } \\
\text { meyakinkan }\end{array}$ \\
\hline 9 & $\begin{array}{l}\text { Mutlak lebih penting } \\
\text { daripada }\end{array}$ & $\begin{array}{l}\text { Suatu aktivitas secara tegas memiliki } \\
\text { kepentingan yang paling tinggi }\end{array}$ \\
\hline $2,4,6,8$ & $\begin{array}{l}\text { Nilai tengah diantara dua } \\
\text { pendapat yang } \\
\text { berdampingan }\end{array}$ & $\begin{array}{l}\text { Dibutuhkan kesepakatan untuk menentukan } \\
\text { tingkat kepentingannya }\end{array}$ \\
\hline
\end{tabular}

Tabel 3. Kuesioner perbandingan berpasangan

\begin{tabular}{llllll}
\hline No & \multicolumn{1}{c}{ Kriteria } & \multicolumn{3}{c}{ Penilaian } & \multicolumn{1}{c}{ Kriteria } \\
\hline 1. & Fasilitas produksi & $9-8-7-6-5-4-3-2$ & 1 & $2-3-4-5-6-7-8-9$ & Kemampuan SDM \\
2. & Fasilitas produksi & $9-8-7-6-5-4-3-2$ & 1 & $2-3-4-5-6-7-8-9$ & Penguasaan informasi \\
3. & Fasilitas produksi & $9-8-7-6-5-4-3-2$ & 1 & $2-3-4-5-6-7-8-9$ & Kemampuan \\
& & & & & organisasi \\
4. & Kemampuan SDM & $9-8-7-6-5-4-3-2$ & 1 & $2-3-4-5-6-7-8-9$ & $\begin{array}{l}\text { Penguasaan informasi } \\
\text { 5. }\end{array}$ \\
Kemampuan SDM & $9-8-7-6-5-4-3-2$ & 1 & $2-3-4-5-6-7-8-9$ & $\begin{array}{l}\text { Kemampuan } \\
\text { organisasi }\end{array}$ \\
6. & Penguasaan informasi & $9-8-7-6-5-4-3-2$ & 1 & $2-3-4-5-6-7-8-9$ & $\begin{array}{l}\text { Kemampuan } \\
\text { organisasi }\end{array}$ \\
\hline
\end{tabular}

\section{Menghitung Technology Contribution} Coefficient/TCC

TCC merupakan koefisien dari kontribusi secara bersama-sama dari keempat komponen teknologi technoware, humanware, infoware dan orgaware. Perhitungan TCC berdasarkan dari kontribusi per komponen teknologi secara individual dan nilai intensitas yang diberikan terhadap masing-masing komponen teknologi. Wiratmaja \& Ma'ruf (2004) mendefinisikan koefisien kontribusi teknologi, dengan formula sebagai berikut:

$T C C=T^{\beta_{t}} x H^{\beta_{h}} x I^{\beta_{i}} x O^{\beta_{o}}$ 
$\mathrm{T}, \mathrm{H}, \mathrm{I}, \mathrm{O}$ adalah kontribusi dari masingmasing komponen teknologi dan $\beta$ merupakan intensitas kontribusi dari masing-masing komponen terhadap koefisien TCC.

Tabel 4. Skala Penilaian TCC (Amiseno, 2006)

\begin{tabular}{cc}
\hline Nilai TCC & Tingkatan Nilai \\
\hline 0,1 & Sangat buruk \\
0,3 & Buruk \\
0,5 & Sedang \\
0,7 & Baik \\
0,9 & Sangat baik \\
1 & Mencapai state of the art \\
\hline
\end{tabular}

Usaha perbaikan dimulai dari komponen dengan intensitas tertinggi karena komponen tersebut paling potensial dalam memberikan kontribusi peningkatan nilai TCC.

\section{HASIL DAN PEMBAHASAN}

Estimasi Derajat Kecanggihan

Komponen Teknologi pada CV. X

Tingkat kecanggihan komponen teknologi ditentukan dengan memberikan skor skala sembilan (1-9). Hasil estimasi terlihat pada Tabel 5.

Tabel 5. Batas bawah dan batas atas tingkat kecanggihan masing-masing komponen teknologi

\begin{tabular}{lcc}
\hline \multicolumn{1}{c}{ Komponen } & Batas bawah & Batas atas \\
\hline Technoware & LT $: 1$ & UT $: 5$ \\
Humanware (pekerja) & LH $: 1$ & UH $: 4$ \\
Humanware (manajer) & LH $: 2$ & UH $: 5$ \\
Infoware & LI $: 1$ & UI $: 4$ \\
Orgaware & LO $: 2$ & UO $: 5$
\end{tabular}

Industri pengolahan cokelat mempunyai batas bawah 1 dan batas atas 5, artinya bahwa fasilitas produksi yang digunakan berada pada tingkat menggunakan mesin manual (misal pengemasan masih manual) dan mesin serbaguna (misal mesin pres dan alat refining). Fasilitas produksi telah menggunakan alat bantu mesin, tetapi operator masih sangat berperan dalam mengoperasikan mesin tersebut. Tingkat pendidikan pekerja setara SMA yang mempunyai kemampuan untuk mengoperasikan, memasang, merawat/mereparasi fasilitas. Tingkat kecanggihan komponen teknologi Humanware pekerja mempunyai batas bawah 1 dan batas atas 4. Tingkat pendidikan dari manajer adalah sarjana dan mempunyai pengalaman yang melebihi pekerja. Tingkat kecanggihan komponen teknologi Humanware manajer mempunyai batas bawah 2 dan batas atas 5. Tingkat kecanggihan komponen teknologi Infoware mempunyai batas bawah 1 dan batas atas 4 , yang berarti industri pengolahan cokelat masih dalam penguasaan informasi yang 
digunakan untuk kepentingan dan caracara penggunaan fasilitas. Tingkat kecanggihan komponen teknologi Orgaware mempunyai batas bawah 2 dan batas atas 5, yang berarti bahwa industri pengolahan cokelat masih tergantung pada pasokan bahan baku tetapi mempunyai kreativitas untuk menghasilkan produk baru.

\section{Penilaian SOTA}

Penilaian technoware dilakukan dengan menganalisis fasilitas proses produksi dalam IKM CV. X. Mesin/alat pengolahan yang digunakan sebagian masih manual dan sebagian mekanik/tenaga gerak. Proses pengolahan rata-rata terdapat dua operasi atau lebih pada satu stasiun produksi. Jenis operasi yang dikerjakan adalah tempering, pencetakan-filling, pendinginan, pengemasan. Rata-rata produk cacat 1-5\%. Intensitas perawatan mesin rata-rata tidak teratur/kadang-kadang. Tingkat keterampilan operator rata-rata sedikit membutuhkan keterampilan.

Pengukuran terhadap benda kerja ratarata diukur secara manual. Desain/pola dari benda kerja sederhana dan kadang menggunakan komputer. Tingkat keselamatan dan keamanan kerja cukup layak.

Komponen humanware IKM CV. $X$ memiliki struktur organisasi yang jelas, sehingga penilaian dilakukan pada pekerja dan manajer. Pekerja biasanya diberikan pelatihan khusus tentang proses pengolahan cokelat. Pekerja dinilai dengan kemampuan mengerti tugas, kemampuan melasanakan tugas, disiplin dan tanggung jawab bervariasi antara cukup dan sangat tinggi, kemampuan berkreasi dan berinovasi rata-rata sangat tinggi, kemampuan merawat fasilitas rata-rata cukup, kemampuan bekerjasama bervariasi antara cukup dan sangat tinggi, dan kemampuan mencapai target produksi berkisar antara $75-100 \%$, rata-rata $87,5 \%$. Manajer dinilai dengan kemampuan mengatasi persoalan, kemampuan bekerjasama dan kemampuan memimpin bervariasi antara cukup, agak tinggi hingga sangat tinggi.

Infoware dinilai dengan jangkauan informasi masih terbatas pada informasi parsial yang hanya terbatas pada lingkungan perusahaan, kemampuan penyampaian informasi berkisar antara kadang-kadang dan selalu, jaringan informasi sudah on line, prosedur komunikasi rata-rata mudah, kemampuan sistem informasi rata-rata dari akses lokal sampai global, dan penyimpanan data-data perusahaan melakukan pembukuan manual dan secara komputerisasi.

Orgaware digunakan untuk memberi gambaran kemampuan mengembangkan organisasi. Orgaware dinilai dengan status perusahaan ratarata otonomi, visi perusahaan sudah berorientasi masa depan, lingkungan yang kondusif rata-rata cukup, kepemimpinan yang memotivasi pegawai dari rata-rata sampai sangat tinggi, fleksibilitas terhadap perubahan rata-rata sampai sangat tinggi, kemampuan kerjasama dengan pihak lain/pemasok rata-rata, kemampuan relasi dengan konsumen rata-rata sampai sangat tinggi, dan kemampuan penyerapan dana dari luar rata-rata.

SOTA dinilai dengan kriteria skor 10 adalah spesifikasi terbaik dan skor 0 adalah spesifikasi terendah. Hasil perhitungan SOTA terlihat pada Tabel 6. 
Tabel 6. Hasil Perhitungan SOTA

\begin{tabular}{|c|c|c|c|c|c|}
\hline \multirow[t]{2}{*}{$\mathrm{K}$} & \multirow[t]{2}{*}{$\mathrm{T}$} & \multicolumn{2}{|c|}{$\mathrm{H}$} & \multirow[t]{2}{*}{$T$} & \multirow[t]{2}{*}{0} \\
\hline & & Pekerja & Manajer & & \\
\hline 1 & 5 & 8 & 8 & 5 & 8 \\
\hline 2 & 5 & 8 & 8 & 7,5 & 10 \\
\hline 3 & 7,5 & 8 & 8 & 10 & 7,5 \\
\hline 4 & 7,5 & 8 & & 8 & 7,5 \\
\hline 5 & 5 & 10 & & 10 & 7,5 \\
\hline 6 & 5 & 5 & & 9 & 5 \\
\hline 7 & 5 & 9 & & & 8 \\
\hline 8 & 6 & 7,5 & & & 5 \\
\hline 9 & 5 & & & & \\
\hline $\begin{array}{l}\text { Total skor } \\
\text { SOTA }\end{array}$ & $\begin{array}{c}51 \\
\text { ST: } 0,567\end{array}$ & $\begin{array}{c}63,5 \\
\text { SHp: } 0,794\end{array}$ & $\begin{array}{c}24 \\
\text { SHm: } 0,800\end{array}$ & $\begin{array}{c}49,5 \\
\text { SI: } 0,825\end{array}$ & $\begin{array}{c}58,5 \\
\text { so: } 0,731\end{array}$ \\
\hline Keterangan: & $\begin{array}{l}\text { ST - SOTA tecl } \\
\text { STHp - SOTA } \\
\text { STHm - SOTA } \\
\text { SI - SOTA infor } \\
\text { SO - SOTA org }\end{array}$ & $\begin{array}{l}\text { ware } \\
\text { nanware pek } \\
\text { nanware ma } \\
\text { e } \\
\text { are }\end{array}$ & & & \\
\hline
\end{tabular}

Penentuan Kontribusi Komponen komponen teknologi dengan menggunakan rumus 5-8, sehingga diperoleh nilai seperti Tabel 7 berikut:

Tabel 7. Hasil Perhitungan Kontribusi Tiap Komponen Teknologi

\begin{tabular}{ll}
\hline \multicolumn{1}{c}{ Komponen Teknologi } & \\
\hline Technoware & 0,363 \\
Humanware & 0,432 \\
Infoware & 0,386 \\
Orgaware & 0,466 \\
\hline
\end{tabular}

Berdasarkan hasil perhitungan nilai kontribusi komponen teknologi menunjukkan bahwa $\mathrm{t}<\mathrm{i}<\mathrm{h}<0$ dimana komponen technoware merupakan komponen yang memiliki nilai kontribusi terkecil pada kinerja CV. X yaitu sebesar $36,3 \%$ diikuti komponen infoware. Menurut Indrawati (2003), industri kecil yang bergerak di sektor pangan memiliki kontribusi komponen teknologi paling rendah pada technoware yaitu sebesar 20-30\%, hal ini disebabkan tingkat teknologi (penggunaan fasilitas produksi) masih rendah karena menggunakan peralatan manual atau semi manual sehingga kontribusi terhadap output tidak optimal.
Pengkajian Intensitas Kontribusi Komponen (B)

Nilai intensitas kontribusi komponen teknologi didapatkan dari pemberian bobot/nilai melalui kuesioner oleh manajer CV. X. Berdasarkan hasil pengolahan data kuesioner, diperoleh nilai intensitas masing-masing komponen yaitu: $\beta_{\mathrm{t}}: 0,214 ; \beta_{\mathrm{h}}=0,214 ; \beta_{\mathrm{i}}$ $=0,488 ; \beta_{0}=0,085$

Hasil perhitungan menunjukkan bahwa komponen infoware memiliki nilai intensitas tertinggi yaitu 0,488 , diikuti oleh komponen technoware dan humanware. Bila diurutkan, maka nilai intensitas masing-masing komponen tersebut sebagai berikut: $\beta i>\beta t=\beta h>$ ßo. Berdasarkan hasil perhitungan nilai kontribusi komponen teknologi dan nilai intensitas kontribusi komponen teknologi, menunjukkan bahwa kontribusi komponen teknologi yang 
perlu ditingkatkan adalah komponen infoware dan technoware didukung oleh hasil penilaian intensitas kontribusi komponen teknologi bahwa komponen infoware, technoware dan humanware merupakan komponen teknologi dengan nilai skor tertinggi yang harus menjadi perhatian manajemen dalam perencanaan pengembangan komponen teknologi dimasa yang akan datang.

\section{Perhitungan TCC}

Perhitungan dilakukan dengan menggunakan persamaan (10), dan diperoleh nilai TCC sebesar 0,3966. Sejalan dengan penelitian Indrawati (2003) yang dilakukan pada industri kecil yang bergerak di sektor pangan, diperoleh nilai TCC sebesar 0,3642. Jika dihubungkan dengan nilai penilaian yang dinormalkan bahwa nilai 1 merupakan nilai yang mencapai SOTA (Tabel 6), maka nilai TCC dari CV. X berada pada level buruk hingga sedang. Hal ini diartikan bahwa kinerja pada kegiatan produksi industri pengolahan cokelat di CV. X masih belum memuaskan, dan perlu usaha perbaikan pada masing-masing komponennya.

\section{Analisis Gap}

Analisis gap dilakukan dengan membandingkan kontribusi teknologi CV. X dengan kompetitornya, yaitu PT. $Y$. Dengan cara yang sama, dilakukan penilaian teknologi untuk PT. Y, dan diperoleh nilai kontribusi komponen teknologi sebagai berikut: komponen technoware sebesar 40,7\%; humanware sebesar $43,2 \%$, infoware sebesar $37,5 \%$ dan orgaware sebesar $47,2 \%$ serta nilai TCC PT. Y adalah sebesar 0,4017. Kontribusi komponen teknologi CV. X dan PT. Y diplot dengan diagram labalaba untuk mengetahui posisi komponen teknologi CV. X terhadap PT. Y, seperti pada Gambar 2.

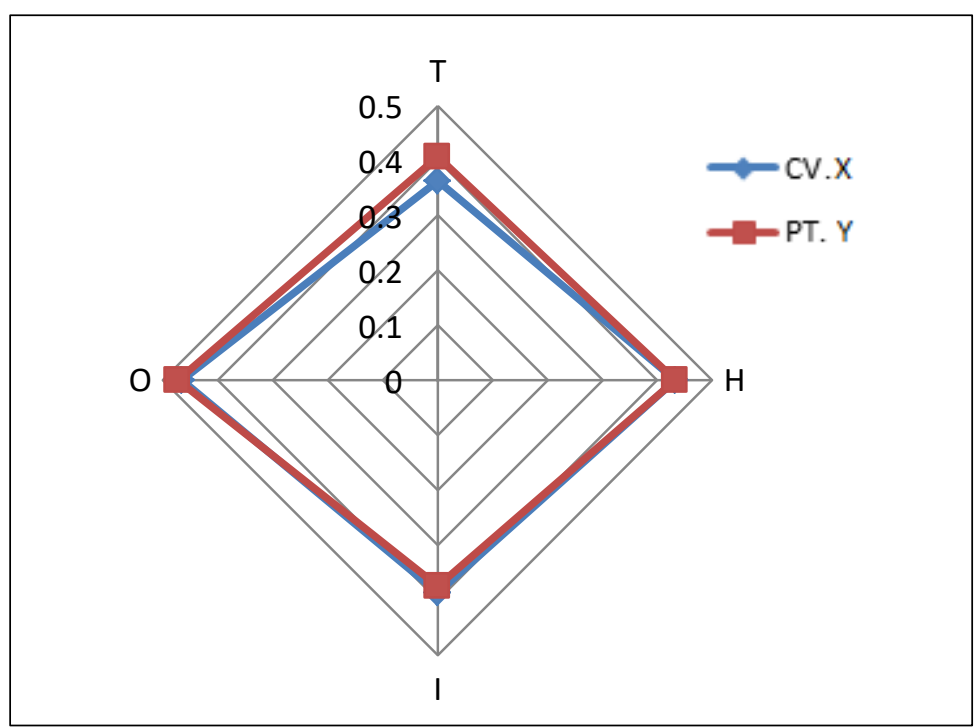

Gambar 2. Grafik THIO Industri Pengolah Kakao

Terlihat bahwa CV. $\mathrm{X}$ mempunyai komponen teknologi yang berada di bawah PT. Y. Alasan kesenjangan ini dapat dirunut kebelakang dengan melihat kontribusi komponennya. Pada gambar 4. terlihat bahwa CV. X tertinggal pada komponen technoware dan orgaware, sehingga pada usaha perbaikan TCC juga perlu memprioritaskan kedua komponen tersebut. 
Rekomendasi strategi berdasarkan komponen teknologi

Berdasarkan penilaian teknologi, dilihat dari nilai TCC, CV. X berada pada level buruk hingga sedang. Keempat komponen teknologi (technoware, humanware, infoware dan orgaware) memberikan kontribusi yang berbeda dalam meningkatkan nilai kontribusi teknologi total (TCC). Intensitas komponen teknologi infoware mempunyai nilai paling tinggi, sehingga infoware merupakan komponen prioritas untuk ditingkatkan. Dari analisis gap, CV. X mempunyai nilai TCC yang lebih rendah dari kompetitornya, dengan komponen yang masih tertinggal adalah technoware dan orgaware. Berdasarkan hasil penilaian teknologi, dapat diusulkan strategi teknologi untuk CV. X adalah: Meningkatkan kemampuan infoware yang dapat menambah memperluas jaringan distribusi; Memperbaiki technoware yang dapat meningkatkan fleksibilitas, sehingga dapat menekan biaya produksi dan menurunkan harga produk yang selama ini dinilai lebih tinggi dibanding harga produk cokelat lokal lainnya serta meningkatkan kemampuan berinovasi sehingga CV. $X$ dapat memproduksi lebih banyak varian cokelat dalam bentuk, ukuran dan harga; Meningkatkan humanware yang dapat menambah keterampilan tenaga kerja; Meningkatkan kemampuan orgaware yang dapat memperbaiki kemampuan inovasi sehingga dapat menambah keunggulan daya saing IKM. Program perbaikan dapat dilihat pada Tabel 8 .

Tabel 8. Strategi Teknologi untuk CV. X

\begin{tabular}{|c|c|c|}
\hline $\begin{array}{c}\text { Aspek } \\
\text { Teknologi }\end{array}$ & Strategi & Program Perbaikan \\
\hline Technoware & $\begin{array}{l}\text { Peningkatan fleksibilitas } \\
\text { dan inovasi }\end{array}$ & $\begin{array}{l}\text { - Optimalisasi kemampuan fasilitas produksi } \\
\text { untuk meminimalkan biaya produksi } \\
\text { - Inovasi desain produk untuk meningkatkan } \\
\text { fleksibiltas dan daya saing produk }\end{array}$ \\
\hline Humanware & $\begin{array}{l}\text { Peningkatan keterampilan } \\
\text { tenaga kerja }\end{array}$ & - Pendidikan dan pelatihan tenaga kerja \\
\hline Infoware & $\begin{array}{l}\text { - Peningkatan sistem } \\
\text { informasi perusahaan } \\
\text { - Peningkatan kegiatan } \\
\text { promosi dan perluasan } \\
\text { jaringan distribusi }\end{array}$ & $\begin{array}{l}\text { - Pelatihan komputer dan jaringan internet } \\
\text { - Memperluas ke daerah Makassar, Medan, } \\
\text { Batam, dan retail seperti supermarket: } \\
\text { Carefour, Hypermart, dll. serta melakukan } \\
\text { promosi online melalui media sosial, } \\
\text { internet, dll } \\
\text { - Meningkatkan kecepatan pengiriman }\end{array}$ \\
\hline Orgaware & $\begin{array}{l}\text { Perbaikan sistem } \\
\text { manajemen perusahaan }\end{array}$ & $\begin{array}{l}\text { - Pelatihan manajemen untuk meningkatkan } \\
\text { kemampuan }\end{array}$ \\
\hline
\end{tabular}

\section{SIMPULAN}

Komponen infoware memiliki kontribusi komponen paling tinggi dibanding tiga komponen lainnya dan diprioritaskan untuk diperbaiki. Tetapi berdasarkan intensitas komponen teknologi, komponen technoware dan humanware juga perlu diprioritaskan untuk diperbaiki. Analisis gap menunjukkan bahwa $\mathrm{CV}$. $\mathrm{X}$ masih tertinggal dari PT. $Y$ dalam hal technoware dan orgaware. Rekomendasi strategi perbaikan komponen teknologi pada CV. X harus menyeluruh, melibatkan semua aspek komponen teknologi dari infoware, technoware, humanware dan orgaware.

\section{DAFTAR PUSTAKA}

1. Amiseno, Aga. 2006. Identifikasi Tingkat Kontribusi Teknologi pada Fasilitas Pengelolaan Frequent Flyer Program 
dengan Menggunakan Model

Teknometrik (Studi Kasus: PT. Garuda Indonesia), Tugas Sarjana. Institut Teknologi Bandung. Bandung.

2. Anshori, M. 2005. Usulan Model Keputusan Multikriteria Terintegrasi untuk Pemilihan UKM Penerima Pinjaman Lunak di Wilayah Surabaya. Tesis Teknik Industri-Institut Teknologi Sepuluh November. Surabaya.

3. Badan Pengkajian dan Penerapan Teknologi. 2012. "Panduan Pengukuran Tingkat Kesiapan Teknologi : TeknoMeter". BPPT. Jakarta.

4. Budikania, Trisutanti. 2008. Analisis Kontribusi Teknologi pada Industri. Tesis Teknik Manajemen IndustriInstitut Teknologi Bandung. Bandung.

5. Edy, Suharyanto, dan Mulato, Sri. 2010. Teknologi Hilir Kakao untuk Pengolahan Makanan Cokelat. Teknologi dan Manajemen Pengolahan Aneka Produk Cokelat. Pusat Penelitian Kopi dan Kakao Indonesia, Jember.

6. Hany I. 2000. Analisis Kandungan Teknologi Terhadap Performansi Bisnis Industri Skala Kecil. Tesis. www.ITB.ac.id. 20 Februari 2020. Hal: 7-50.

7. Indrawati, S.W. 2003. Analisis Pengaruh Komponen Teknologi Technoware, Humanware, Infoware, dan Orgaware terhadap Faktor Utama Daya Saing Industri Kecil. Institut Teknologi Bandung. Bandung.

8. Mubin, Ahmad. 2007. Analisis Kandungan Teknologi sebagai Upaya Peningkatan Daya Saing Industri Kecil Menengah Bahan Bangunan di Kabupaten Malang. Malang.

9. Nazaruddin. 2008. Manajemen Teknologi. Graha IImu: Yogyakarta.

10. UNESCAP. 1988. Tokyo Plan on Technology for Development in Asia and Pacific (4 ${ }^{\text {th }}$ Ed.). Banglore: Asian and Pacific Centre for Transfer Oftechnology.

11. Virliantarto, N. 2017. Studi Kesiapan Teknologi PT. PAL Indonesia untuk Pembangunan Kapal Kontainer 100 teus secara Massal dengan Teknologi Modular. Tesis. Program Magister Teknik Produksi dan Material Kelautan Departemen Teknik Perkapalan Fakultas Teknologi Kelautan Institut
Teknologi Surabaya.

Sepuluh November.

12. Wiratmaja, I.I. 2011. Materi Kuliah Manajemen Strategi. Jurusan Teknik dan Manajemen Industri. Institut Teknologi Bandung. Bandung.

13. Wiratmaja, I.I. dan Ma'ruf A. 2004. The Assesment of Technology in Supporting Industry Located at Tegal Industrial Park. Proceedings of Marine Transportation Engineering Seminar. Osaka University. Jepang. 